\title{
Titanium Dioxide Nanoparticles-Mediated In Vitro Cytotoxicity Does Not Induce Hsp70 and Grp78 Expression in Human Bronchial Epithelial A549 Cells
}

\author{
Sasitorn Aueviriyavit • Duangkamol Phummiratch • \\ Kornphimol Kulthong - Rawiwan Maniratanachote
}

Received: 20 December 2011 / Accepted: 23 March 2012

(C) Springer Science+Business Media, LLC 2012

\begin{abstract}
Titanium dioxide nanoparticles $\left(\mathrm{TiO}_{2} \mathrm{NPs}\right)$ are increasingly being used in various industrial applications including the production of paper, plastics, cosmetics and paints. With the increasing number of nano-related products, the concern of governments and the general public about the health and environmental risks, especially with regard to occupational and other environmental exposure, are gradually increasing. However, there is insufficient knowledge about the actual affects upon human health and the environment, as well as a lack of suitable biomarkers for assessing $\mathrm{TiO}_{2} \mathrm{NP}$-induced cytotoxicity. Since the respiratory tract is likely to be the main exposure route of industrial workers to $\mathrm{TiO}_{2} \mathrm{NPs}$, we investigated the cytotoxicity of the anatase and rutile crystalline forms of $\mathrm{TiO}_{2} \mathrm{NPs}$ in A549 cells, a human alveolar type II-like epithelial cell line. In addition, we evaluated the transcript and protein expression levels of two heat shock protein (HSP) members, Grp78 and Hsp70, to ascertain their suitability as biomarkers of $\mathrm{TiO}_{2} \mathrm{NP}$-induced toxicity in the respiratory system. Ultrastructural observations confirmed the presence of $\mathrm{TiO}_{2} \mathrm{NPs}$ inside cells. In vitro exposure of A549 cells to the anatase or rutile forms of $\mathrm{TiO}_{2} \mathrm{NPs}$ led to cell death and induced intracellular ROS generation in a dose-dependent manner, as determined by the MTS and dichlorofluorescein (DCF) assays, respectively. In contrast, the transcript and protein expression levels of
\end{abstract}

Electronic supplementary material The online version of this article (doi:10.1007/s12011-012-9403-z) contains supplementary material, which is available to authorized users.

S. Aueviriyavit $\cdot$ D. Phummiratch $\cdot$ K. Kulthong

R. Maniratanachote $(\triangle)$

National Nanotechnology Center, National Science and Technology Development Agency,

111 Thailand Science Park, Phahonyothin Road,

Klong Luang, Pathumthani 12120, Thailand

e-mail: rawiwan@nanotec.or.th
Hsp70 and Grp78 did not change within the same $\mathrm{TiO}_{2} \mathrm{NPs}$ dose range $(25-500 \mu \mathrm{g} / \mathrm{ml})$. Thus, whilst $\mathrm{TiO}_{2} \mathrm{NPs}$ can cause cytotoxicity in A549 cells, and thus potentially in respiratory cells, Hsp70 and Grp78 are not suitable biomarkers for evaluating the acute toxicological effects of $\mathrm{TiO}_{2} \mathrm{NPs}$ in the respiratory system.

Keywords $\mathrm{TiO}_{2}$ nanoparticles $\cdot$ Cytotoxicity $\cdot$ Heat shock protein $\cdot \mathrm{Hsp} 70 \cdot \mathrm{Grp} 78 \cdot$ A549 cells

\section{Introduction}

The industrial use of metallic oxide nanoparticles (NPs) in a wide variety of applications has rapidly expanded over the last decade. Because of its high stability, anticorrosiveness and photocatalytic properties, titanium dioxide nanoparticles $\left(\mathrm{TiO}_{2} \mathrm{NPs}\right)$ are among the most frequently used metallic oxide NPs in various human products, such as cosmetics, sunscreen, toothpaste and paints [1]. Moreover, $\mathrm{TiO}_{2} \mathrm{NPs}$ have been used in the manufacturing industry [2] and environmentally to decontaminate water, air and soil, including the decontamination of agrochemicals [3, 4]. With the rapid increase in the number of nano-related products comes an increasing concern of governments and the general public about their safety to humans and the environment. Indeed, the human health effects of $\mathrm{TiO}_{2} \mathrm{NP}$ exposure, as well as their impact on the environment, are not under regulatory control [5], which then serves to raise concern further.

Because of their very small size, $\mathrm{TiO}_{2} \mathrm{NPs}$ have specific physicochemical characteristics and can enter the human body through several potential routes, including inhalation, skin contact, ingestion and parenteral [6]. Among the different potential exposure routes, inhalation is likely to be the main entry route of manufactured $\mathrm{TiO}_{2}$ into the body of 
industrial workers. Up to date, the safety aspects of $\mathrm{TiO}_{2} \mathrm{NPs}$ in the respiratory system have been studied in various in vitro models that are derived from human bronchial epithelial cells or lung fibroblast cells, and in vivo models using rodent models. Most of the studies have focused on the cytotoxic effects, toxic mechanisms, accumulation and clearance of $\mathrm{TiO}_{2} \mathrm{NPs}$. For instance, it has been reported that $\mathrm{TiO}_{2} \mathrm{NPs}$ are rapidly internalized in the A549 human alveolar derived cell line and become distributed in the cytoplasm and intracellular vesicles [7], whilst $\mathrm{TiO}_{2} \mathrm{NPs}$ induce oxidative stress and cause genotoxicity in human lung fibroblast cells via DNA-adduct formation [8]. Furthermore, it has been reported that $\mathrm{TiO}_{2} \mathrm{NPs}$ cause cell death via induction of mitochondrial apoptosis in the BEAS2B human bronchial epithelial cell derived cell line, and that this involves Bax, cytochrome $\mathrm{C}$, p53 and Bcl-2 [9]. With respect to the particle uptake and clearance aspects of $\mathrm{TiO}_{2} \mathrm{NPs}$, lung surface macrophages do not efficiently phagocytose these ultrafines, but take them up in a rather sporadic and unspecific pathway in the rat model [10]. However, there are far fewer studies on the cellular responses and possible biomarker(s) for assessing the toxicity of $\mathrm{TiO}_{2} \mathrm{NPs}$ in the respiratory system.

One of the key cellular responses to toxicant exposure which could potentially be used as an early marker of toxicity is the induction of heat shock protein (HSP) expression [11]. HSPs can function as molecular chaperones, facilitating protein folding, preventing protein aggregation and targeting improperly folded proteins to specific degradative pathways [12]. Among them, the 70-kDa HSP family (Hsp70) consist of at least 11 genes, including Hsp 70, Hsc70, Grp 75 and Grp 78, the protein products of which have housekeeping functions in the cell and are built-in components of protein folding, signal transduction pathways and quality control functions, where they proof read the structure of proteins and repair misfolded conformations [13-15]. The Hsp70 protein family differs from the other classes of HSPs in being one of the most highly conserved members and the first to be induced under stress conditions [14]. Among the members of the Hsp70 family, Hsp70 itself is an important cytosolic protein in the HSPA chaperone machine and the strongest stress induced protein [16]. Their main chaperone functions are to help the folding of proteins and the refolding of denatured proteins [15]. Another member of the HSP family, Grp78 (glucose-regulated protein of $78 \mathrm{kDa}$; $\mathrm{BiP}$ ) is a major endoplasmic reticulum (ER) chaperone protein that facilitates protein folding and assembly, protein quality control, $\mathrm{Ca}^{2+}$-binding and regulating ER stress signaling [17]. Grp78 is induced by physiological stresses that perturb the ER function and homeostasis and protects against tissue or organ damage under these pathological conditions [18]. Grp78, therefore, is widely used as a marker for ER stress to toxicants. However, the involvement of Hsp70 and Grp78 in biological responses to $\mathrm{TiO}_{2} \mathrm{NPs}$ in the respiratory system is currently unknown.

Therefore, in this study, we aimed to examine possible biomarker(s) in response to $\mathrm{TiO}_{2} \mathrm{NP}$-induced toxicity in A549 cells in vitro (representative of the respiratory system) by focusing on the transcriptional and post-translational expression levels of Hsp70 and Grp78.

\section{Materials and Methods}

\section{Nanoparticles}

Anatase and rutile crystalline forms of $\mathrm{TiO}_{2} \mathrm{NPs}$ were purchased from Sigma-Aldrich (St. Louis, MO). The product insert information indicates particle sizes of less than $25 \mathrm{~nm}$ with a specific surface area of $200-220 \mathrm{~m}^{2} / \mathrm{g}$.

\section{Particles Characterization}

The $\mathrm{TiO}_{2} \mathrm{NP}$ morphology was analyzed by transmission electron microscopy (TEM) using a JEM-2010 microscope (Jeol, Japan). A drop of the $\mathrm{TiO}_{2} \mathrm{NP}$ suspension (from a feedstock of $0.01 \mathrm{~g} \mathrm{TiO}_{2} \mathrm{NP}$ powder diluted to $20 \mathrm{ml}$ by ethanol and sonicated for $5 \mathrm{~min}$ ) was placed on a carbon film supported by a 200 -mesh copper grid and the solvent was removed by drying overnight in a desiccator. TEM images of the $\mathrm{TiO}_{2} \mathrm{NPs}$ were collected at $200 \mathrm{keV}$ and 100,000 times magnification. An energy-dispersive X-ray analysis (EDX) was used to confirm the presence of titanium.

Particle size and polydispersity index (PDI) of $\mathrm{TiO}_{2} \mathrm{NPs}$ were measured by dynamic light scattering (DLS) with a Zetasizer Nanoseries S4700 (Malvern, UK). $\mathrm{TiO}_{2} \mathrm{NPs}$ were dispersed in ultrapure water or Ham's F12K at a concentration of $1,000 \mu \mathrm{g} / \mathrm{ml}$. To this end, after sonication for 5 or $60 \mathrm{~min}$, the $\mathrm{TiO}_{2} \mathrm{NP}$ suspension was 10 -fold diluted with distilled water or $\mathrm{CM}$, and then analyzed by DLS.

\section{Cell Culture and Preparation of Exposure Suspension}

A549 cells, derived from the human alveolar type II-like epithelial cell line, were obtained from the American Type Culture Collection (CCL-185; ATCC, Manassas, VA). The cells were cultured in complete media (CM; Ham's F12K medium (Invitrogen, Carlsbad, CA) supplemented with $10 \%(\mathrm{v} / \mathrm{v})$ fetal bovine serum) at $37{ }^{\circ} \mathrm{C}$ in humidified atmosphere with $5 \%(\mathrm{v} / \mathrm{v}) \mathrm{CO}_{2}$ and subcultured by trypsinization. Before the treatment, A549 cells at a passage number less than 40 were grown overnight to reach about $80 \%$ confluence. $\mathrm{TiO}_{2} \mathrm{NPs}$ were dispersed in the media without FBS at a concentration of $1,000 \mu \mathrm{g} / \mathrm{ml}$ by sonication for $5 \mathrm{~min}$ and diluted with $\mathrm{CM}$ prior to addition to the A549 cells. 
Cytotoxicity Assay

A549 cells $\left(5 \times 10^{3}\right.$ cells/well $)$ were seeded into each well of a 96-well plate in $100 \mu \mathrm{l}$ of $\mathrm{CM}$ and grown for $24 \mathrm{~h}$ before treatment. The medium was then removed and replaced with $100 \mu \mathrm{l}$ of the $\mathrm{TiO}_{2} \mathrm{NP}$ suspension in $\mathrm{CM}$ at final concentrations of $5,10,25,50,100,250$ and $500 \mu \mathrm{g} / \mathrm{ml}$, which is equivalent to $1.563,3.125,7.813,15.625,31.25,78.13$ and $156.3 \mu \mathrm{g} / \mathrm{cm}^{2}$, respectively, and incubated for $24 \mathrm{~h}$. The cytotoxicity of the added $\mathrm{TiO}_{2} \mathrm{NPs}$ was subsequently assessed using the CellTiter 96 Aqueous One Solution Reagent (Promega, Madison, WI), as per the manufacturer's instructions, which contains 3-(4,5-dimethylthiazol-2-yl)-5-(3carboxymethoxyphenyl)-2-(4-sulfophenyl)- $2 H$-tetrazolium (MTS). The absorbance of the resulting solubilized formazan product was measured by monitoring the absorbance at $490 \mathrm{~nm}$ using a SpectraMax M2 microplate reader (Molecular Devices, Sunnyvale, CA). Results are shown as the relative percentage cell viability (which assumes no differences between treatments in cell division or mitochondrial metabolism and hence is all due to the number of viable cells), calculated by comparing the observed absorbance to that of the control cells (no added $\mathrm{TiO}_{2} \mathrm{NPs}$ ).

\section{Intracellular Reactive Oxygen Species (ROS) Generation}

The induction of ROS generation by $\mathrm{TiO}_{2} \mathrm{NPs}$ was measured by dichlorofluorescein (DCF) assay [20]. Briefly, A549 cells $\left(1 \times 10^{4}\right.$ cells/well $)$ were seeded into each well of a 96 -well culture plate and incubated at $37^{\circ} \mathrm{C}$ for $24 \mathrm{~h}$. The cells were subsequently incubated with $50 \mu \mathrm{M} 2^{\prime}, 7^{\prime}$-dichlorodihydrofluorescein diacetate $\left(\mathrm{H}_{2}\right.$-DCF-DA; Molecular Probes, Grand Island, NY) dispersed in phosphate buffered saline $\mathrm{pH} 7.4$ (PBS) for $40 \mathrm{~min}$ in the dark. The cells were washed with PBS and then exposed to various concentrations of the anatase or rutile crystalline forms of $\mathrm{TiO}_{2} \mathrm{NPs}$ at final concentrations of $5,10,25,50,100,250$ and $500 \mu \mathrm{g} / \mathrm{ml}$ for $2 \mathrm{~h}$. Hydrogen peroxide $(5 \mathrm{mM})$ was used as a positive control in the assay. The fluorescent intensity of $2^{\prime}, 7^{\prime}$-dichlorofluorescein in the cells was measured at $485 / 528 \mathrm{~nm}$ by a microplate reader system (PowerWave XS2, BioTek, Winooski, VT).

\section{Side Scatter Measurements}

The degree of $\mathrm{TiO}_{2} \mathrm{NPs}$ uptake or adsorption on cellular membranes was determined by measuring side scatter pulse area (SSC-A) parameter of FACS analysis as described previously [19]. Briefly, A549 cells were plated into a 12-well plate at $6 \times 10^{4}$ cells/well and cultured for $24 \mathrm{~h}$. After $\mathrm{TiO}_{2} \mathrm{NP}$ exposure, the cells were trypsinized, centrifuged and resuspended in PBS before subjected to FACS analysis using a flow cytometer (FACSAria II; Becton Dickinson, San Jose, CA). The mean of SSC-A was measured by FACSDiva software (BD) based on 10,000 events.

\section{TEM Analysis}

A549 cells $\left(8 \times 10^{5}\right.$ cells $)$ were plated into a 10 -cm Petri dish and cultured for $24 \mathrm{~h}$ before treatment with $100 \mu \mathrm{g} / \mathrm{ml} \mathrm{TiO}_{2} \mathrm{NPs}$ for $24 \mathrm{~h}$. The cell pellets were collected, fixed with $2.5 \%$ glutaraldehyde and postedfixed in $1 \%$ osmium tetroxide. The specimens were subsequently dehydrated in a graded series of ethanol and embedded in a mixture of Spurr resin. After polymerized, ultra-thin sections were prepared with a Leica Ultracut microtome (Leica, Deerfield, IL), collected on copper grids, and contrasted with uranyl acetate and lead acetate. Samples were finally imaged using a TEM at $120 \mathrm{keV}$ (FEI Tecnai T20, the Netherlands).

Quantification of the Expression Levels of Grp78 and Hsp70 mRNAs

A549 cells were seeded into each well of a 6-well culture plate at $1.5 \times 10^{5}$ cells/well and incubated at $37^{\circ} \mathrm{C}$ for $24 \mathrm{~h}$. The cells were then exposed to the anatase or rutile crystalline forms of $\mathrm{TiO}_{2} \mathrm{NPs}$ at a final concentration of 25, 50, 100,250 or $500 \mu \mathrm{g} / \mathrm{ml}$. Total RNA was isolated by using a FastPure RNA Kit (Takara, Japan) following the manufacturer's instructions. The isolated total RNA was subsequently treated with DNase I (Takara) to remove contaminating genomic DNA. The RNA concentration was determined at $260 \mathrm{~nm}$ by Nanodrop 2000C (Thermo Scientific, Wilmington, NC). The cDNA was then generated with a random hexamer by using a high-capacity cDNA Reverse Transcription Kit (Applied Biosystems, Foster, CA). The expression level of Grp78 and Hsp 70 mRNA transcripts in A549 cells were then measured by quantitative real-time PCR carried out on an ABI PRISM 7500 Fast (Applied Biosystems) using SYBR green (Applied Biosystems). Each PCR reaction mixture, at a final volume of $15 \mu \mathrm{l}$, contained of $1 \times$ Power SYBR green Mastermix, $0.25 \mu \mathrm{M}$ of each of the forward and reverse primer (see Table 1) and $37.5 \mathrm{ng}$ cDNA template. PCR reactions were performed at $95{ }^{\circ} \mathrm{C}$ for $10 \mathrm{~min}$ followed by 40 cycles of $95{ }^{\circ} \mathrm{C}$ for $15 \mathrm{~s}$ and $60{ }^{\circ} \mathrm{C}\left(62{ }^{\circ} \mathrm{C}\right.$ for $H s p 70)$ for $1 \mathrm{~min}$. The expression levels of Grp 78 and Hsp70 mRNAs were normalized to the expression level of GAPDH as an endogenous control gene. The primers were designed using the Oligo 4.0-s software (Molecular Biology Insights, Cascade, CO) and confirmed for likely gene specificity by Primer-BLAST (http://www.ncbi.nlm. nih.gov/tools/primer-blast/) searching of the NCBI GenBank database. 
Table 1 Sequences of the primers used in the real-time PCR

\begin{tabular}{|c|c|c|c|c|}
\hline Gene name & GenBank accession No. & Location $^{\mathrm{a}}$ (bp) & Expected size (bp) ${ }^{b}$ & Sequence $\left(5^{\prime}-3^{\prime}\right)^{\mathrm{c}}$ \\
\hline \multirow[t]{2}{*}{ Grp 78} & \multirow[t]{2}{*}{ NM005347.4 } & $725-745$ & \multirow[t]{2}{*}{84} & F: AAACCGCTGAGGCTTATTTGG \\
\hline & & $808-790$ & & R: CTTGGCGTTGGGCATCATT \\
\hline \multirow[t]{2}{*}{ Hsp 70} & \multirow[t]{2}{*}{ NM005345.4 } & $1,799-1,821$ & \multirow[t]{2}{*}{189} & F: TGCAGGAGGCGGAGAAGTACAAA \\
\hline & & $1,987-1,965$ & & R: CCAGCCACGAGATGACCTCTTGA \\
\hline \multirow[t]{2}{*}{$G A P D H$} & \multirow[t]{2}{*}{ NM002046.3 } & $157-178$ & \multirow[t]{2}{*}{104} & F: ACCAGGGCTGCTTTTAACTCTG \\
\hline & & $260-238$ & & R: TGGGTGGAATCATATTGGAACAT \\
\hline
\end{tabular}

${ }^{\text {a }}$ The primer location is shown for the bp numbering of the sequence entry with the given NCBI GenBank accession number

${ }^{\mathrm{b}}$ Expected size of the PCR amplicon in bp

${ }^{\mathrm{c}}$ Primer sequences are shown $5^{\prime}$ to $3^{\prime}$ for: F, forward; R, reverse

\section{Cell Lysate Preparation}

A549 cells $\left(8 \times 10^{5}\right.$ cells $)$ were seeded in a 10 -cm Petri dish in $10 \mathrm{ml}$ of $\mathrm{CM}$ and incubated at $37^{\circ} \mathrm{C}$ for $24 \mathrm{~h}$. The cells were then exposed to various doses of anatase or rutile crystalline forms of $\mathrm{TiO}_{2} \mathrm{NPs}$ at a final concentration of $25,50,100,250$ or $500 \mu \mathrm{g} / \mathrm{ml}$ for 6,12 or $24 \mathrm{~h}$. The cells were then washed and subsequently lysed in cell lysis buffer (50 mM Tris- $\mathrm{HCl}, \mathrm{pH} 8.0,150 \mathrm{mM} \mathrm{NaCl}, 1$ \% (v/v) Nonidet P-40, $1 \mathrm{mM}$ EDTA, $100 \mathrm{mM} \mathrm{NaF}, 0.2 \mathrm{mM} \mathrm{Na} \mathrm{VO}_{4}$ ) supplemented with protease inhibitor cocktail (Sigma) for $30 \mathrm{~min}$ at $4{ }^{\circ} \mathrm{C}$ with gentle agitation. The cell debris was consequently removed by centrifugation at $10,000 \times \mathrm{g}$ for $20 \mathrm{~min}$ at $4{ }^{\circ} \mathrm{C}$. Cell lysates were kept at $-80{ }^{\circ} \mathrm{C}$ until analysis. The protein concentration in each sample was measured by using a BCA protein assay kit (Thermo Scientific, Illinois, USA), as per the manufacturer's instructions.

\section{Western Blot Analysis}

The cell lysates $(10 \mu \mathrm{g}$ protein/lane) were separated on reducing SDS-polyacrylamide gel electrophoresis $(7.5 \%$ $(\mathrm{w} / \mathrm{v})$ acrylamide resolving gel) and transferred to a polyvinylidine fluoride membrane (Pall Life Sciences, Ann Arbor, MI) by Trans-Blot SD Semi-Dry Electrophoretic Transfer Cell (Bio-Rad, UK). The stress proteins, Grp78 and Hsp70, were specifically detected by incubating the membrane with antiKDEL (SPA-827, Stressgen, San Diego, CA) and anti-HSP70 (SPA-820, Stressgen) antibodies (each diluted at 1:1,000) in PBS-S (5 \% (w/v) skim milk in PBS) for $2 \mathrm{~h}$ at room temperature, respectively. Membranes were also incubated at this stage with anti- $\beta$-actin (sc-47778; Santa Cruz Biotechnology, Santa Cruz, CA), diluted 1:500 in PBS-S, for $2 \mathrm{~h}$ as a sample loading control. The membrane was subsequently washed with PBS and incubated with biotinylated-secondary antibodies (2,000 dilution) in PBS-S for $30 \mathrm{~min}$. The membrane was then incubated with
Fig. 1 Characterization of the a anatase and $\mathbf{b}$ rutile crystalline forms of $\mathrm{TiO}_{2} \mathrm{NPs}$. The particle morphology was analyzed by TEM and imaged with a magnification of 100,000 times. The presence of titanium was confirmed by an energydispersive X-ray analysis $(E D X)$. Micrographs and spectra shown are representative of those seen from five fields of view per sample


(B)
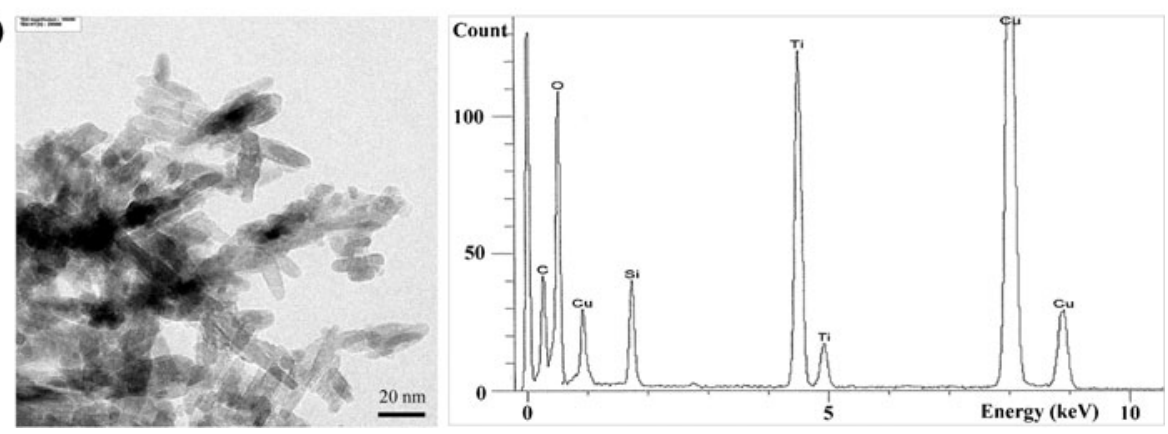
avidin-biotin complex (Santa Cruz Biotechnology) and finally incubated with 3,3'-diaminobenzidinetetrahydrochloride (DAB; a substrate for peroxidase). The protein bands were subsequently imaged by a gel imaging system (AlphaImager, San Jose, CA).

\section{Statistical Analysis}

Data were analyzed by one-way analysis of variance (ANOVA) followed by Dunnett's post hoc test. A value of $p<0.05$ was considered statistically significant.

\section{Results}

\section{$\mathrm{TiO}_{2} \mathrm{NP}$ Characterization}

According to the supplier's product information, the anatase and rutile $\mathrm{TiO}_{2} \mathrm{NPs}$ were each $99.9 \%$ pure with an average particle size of less than $25 \mathrm{~nm}$ and a specific surface area of $200-220 \mathrm{~m}^{2} / \mathrm{g}$. The morphology and size distribution of the anatase and rutile $\mathrm{TiO}_{2} \mathrm{NPs}$ were confirmed by dispersing $\mathrm{TiO}_{2} \mathrm{NPs}$ in an aqueous solution, and then measured in the dry and hydrated states by TEM-EDX and DLS analyses, respectively. The size of the anhydrous anatase and rutile $\mathrm{TiO}_{2} \mathrm{NPs}$, as revealed by TEM analysis, revealed a median particle size of about $20 \mathrm{~nm}$, and both forms showed a similar pattern of two peaks (high and small) of titanium in the EDX spectra (Fig. 1a and b). For the hydrated size, as evaluated by DLS, the $\mathrm{TiO}_{2} \mathrm{NPs}$ dispersed in DI water tended to form agglomerates with a net size distribution at $542 \pm 8.21$ and $321.53 \pm 16.18 \mathrm{~nm}$ for the anatase and rutile forms, respectively (Table 2). Although increasing the sonication time from 5 to 60 min reduced the diameter of the anatase

Table 2 Hydrated $\mathrm{TiO}_{2} \mathrm{NP}$ (agglomerate) size and polydispersity index

\begin{tabular}{llc}
\hline Sample preparation & $\begin{array}{c}\text { a } \\
\text { Hydrodynamic } \\
\text { diameter }(\mathrm{nm})^{\mathrm{b}}\end{array}$ & $\begin{array}{l}\text { Polydispersity index } \\
(\mathrm{nm})^{\mathrm{b}}\end{array}$ \\
\hline Anatase $\mathrm{TiO}_{2} \mathrm{NPs}$ & & \\
$\mathrm{DW}$, sonication for $5 \mathrm{~min}$ & $542.5 \pm 8.2$ & $0.258 \pm 0.014$ \\
$\mathrm{DW}$, sonication for $60 \mathrm{~min}$ & $499.0 \pm 3.2$ & $0.304 \pm 0.026$ \\
$\mathrm{CM}$, sonication for $5 \mathrm{~min}$ & $2,865 \pm 381.7$ & $0.593 \pm 0.163$ \\
$\mathrm{CM}$, sonication for $60 \mathrm{~min}$ & $2,503 \pm 328.2$ & $0.504 \pm 0.189$ \\
$\mathrm{Rutile} \mathrm{TiO}_{2} \mathrm{NPs}$ & & \\
$\mathrm{DW}$, sonication for $5 \mathrm{~min}$ & $321.5 \pm 16.2$ & $0.370 \pm 0.021$ \\
$\mathrm{DW}$, sonication for $60 \mathrm{~min}$ & $338.5 \pm 17.1$ & $0.469 \pm 0.029$ \\
$\mathrm{CM}$, sonication for $5 \mathrm{~min}$ & $4,235 \pm 662.7$ & 1 \\
$\mathrm{CM}$, sonication for $60 \mathrm{~min}$ & $2,623 \pm 326.6$ & $0.842 \pm 0.075$ \\
\hline
\end{tabular}

${ }^{\text {a }}$ Samples were suspended in distilled water (DW) or CM and sonicated for either 5 or $60 \mathrm{~min}$

${ }^{\mathrm{b}}$ Data are shown as the mean $\pm \mathrm{SD}$ and are derived from triplicate measurement agglomerates $\sim 1.1$-fold, no significant change in agglomerate size was noted for the rutile NPs. Likewise, for the $\mathrm{TiO}_{2} \mathrm{NP}$ size distribution, as measured by the DLS, the PDI was not decreased by increasing the sonication time from 5 to $60 \mathrm{~min}$, but rather was increased. In the experimental condition of $\mathrm{TiO}_{2} \mathrm{NPs}$ dispersed in $\mathrm{CM}$, high degree of agglomeration was observed. The hydrodynamic diameter sizes of anatase $\mathrm{TiO}_{2} \mathrm{NPs}$ in $\mathrm{CM}$ at 5 and 60 min sonication were $\sim 5.3$ - and 5fold larger than those in DI water, respectively. The increased sonication time appeared no effect on their hydrodynamic size. In contrast, the diameter sizes of rutile $\mathrm{TiO}_{2} \mathrm{NPs}$ dispersed in $\mathrm{CM}$ were decreased up on increasing the sonication time from 5 to $60 \mathrm{~min}$. Although diameter size of rutile $\mathrm{TiO}_{2} \mathrm{NPs}$ at 5 -min sonication was about twice larger than at 60 -min sonication, the long period of sonication could generate heat and induce higher degree of sedimentation. At 5-min sonication, two populations of rutile $\mathrm{TiO}_{2} \mathrm{NP}$ size distribution, in nano-sized range, were demonstrated (Suppl. 1). Therefore, a 5-min sonication of anatase and rutile $\mathrm{TiO}_{2} \mathrm{NPs}$ was used in this study.

\section{In Vitro Cytotoxicity of $\mathrm{TiO}_{2} \mathrm{NPs}$ to the A549 Cell Line}

To investigate the in vitro cytotoxicity of $\mathrm{TiO}_{2} \mathrm{NPs}$, A549 cells in tissue culture were used as an in vitro model system for the airway epithelium. The A549 cells were exposed to various concentrations of $\mathrm{TiO}_{2} \mathrm{NPs}$ for $24 \mathrm{~h}$ and then analyzed by the MTS assay. The anatase form of $\mathrm{TiO}_{2} \mathrm{NPs}$ caused a dose-dependent reduction in the amount of formazan produced, and thus an assumed decreased cell viability or increased cytotoxicity in A549 cells, but only the two highest concentrations tested $(250$ and $500 \mu \mathrm{g} / \mathrm{ml})$ were statistically significant $(p<0.05)$ (Fig. 2a). Rutile $\mathrm{TiO}_{2} \mathrm{NPs}$ also showed a dose-dependent decrease in the cell viability, but this numerical decrease was not statistically significant at the concentrations used in this study (Fig. 2b).

\section{Intracellular ROS Generation}

Since oxidative stress is one of the mechanisms of toxicity related to NP exposure in several cell lines, the intracellular ROS generation in A549 cells after exposure to $\mathrm{TiO}_{2} \mathrm{NPs}$ was investigated using the DCF assay. As shown in Fig. 3, both the anatase and rutile forms of $\mathrm{TiO}_{2} \mathrm{NPs}$ significantly increased the intracellular ROS levels, but this was only at the higher concentrations of $100 \mu \mathrm{g} / \mathrm{ml}$ numerically, and was statistically only significant at 250 and $500 \mu \mathrm{g} / \mathrm{ml}(p<$ $0.05)$. Nevertheless, consistent with the observed results for their ability to induce A549 cell cytotoxicity, the anatase and, to a lesser extent, the rutile forms of $\mathrm{TiO}_{2} \mathrm{NPs}$ tended to induced ROS generation in a concentration-dependent manner. 
Fig. 2 In vitro cytotoxicity of the $\mathbf{a}$ anatase and $\mathbf{b}$ rutile crystalline forms of $\mathrm{TiO}_{2} \mathrm{NPs}$ against A549 cells. A549 cells were incubated with various concentrations of the anatase or rutile crystalline forms of $\mathrm{TiO}_{2} \mathrm{NPs}$ for $24 \mathrm{~h}$ and then the cell viability was determined by the MTS assay. Data are presented as mean $\pm \mathrm{SD}$ of three independent experiments. ${ }^{*} p<0.05$, using a one-way ANOVA for the comparison between untreated and $\mathrm{TiO}_{2} \mathrm{NP}$ exposed cells
(A)

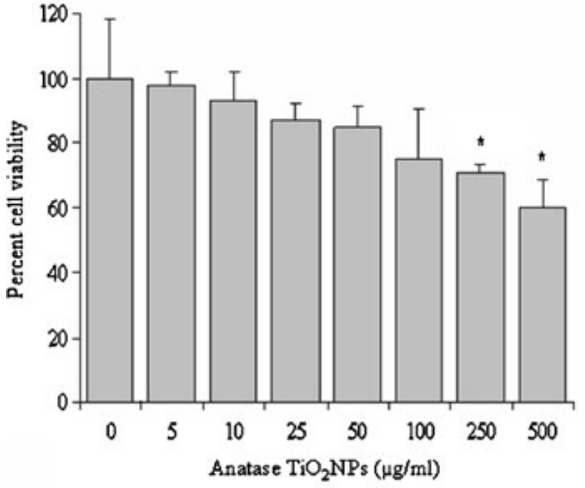

(B)

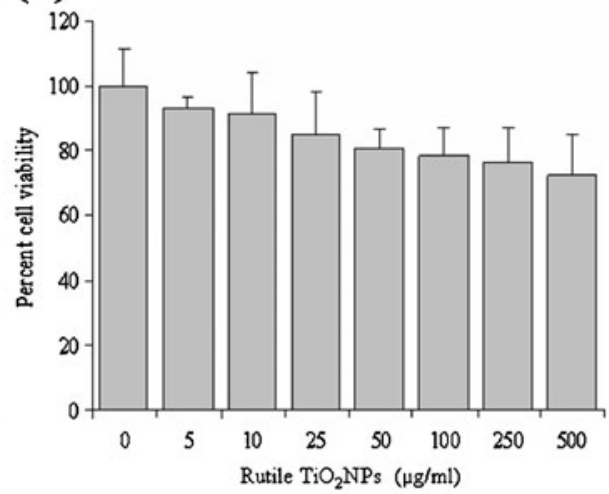

\section{Uptake of $\mathrm{TiO}_{2} \mathrm{NPs}$ into the Cells}

The uptake of $\mathrm{TiO}_{2} \mathrm{NPs}$ into A549 cells was investigated by FACS and TEM analyses. Since, increase of SSC is proportional to cell granularity or complexity, endocytosis or adsorptive nanoparticle interactions to the cells were determined by SSC measurement following $\mathrm{TiO}_{2} \mathrm{NP}$ exposure. As shown in Fig. 4, mean of SSC-A was significantly increased in cells treated with both anatase and rutile $\mathrm{TiO}_{2} \mathrm{NPs}$ at even the low concentrations ( 25 and $50 \mu \mathrm{g} / \mathrm{ml}$ ) used in this study. We further confirmed the internalization of $\mathrm{TiO}_{2} \mathrm{NPs}$ to the cells by TEM analysis. Ultrastructure image demonstrated that $\mathrm{TiO}_{2} \mathrm{NPs}$ could be internalized to the cells and appeared in the cytoplasm, but not in the nucleus (Fig. 5).

\section{Effect of $\mathrm{TiO}_{2} \mathrm{NPs}$ on Grp78 and Hsp70 Transcript} and Protein Expression Levels in the A549 Cell Line

To examine the alteration of stress-related gene expression after exposure to $\mathrm{TiO}_{2} \mathrm{NPs}$, the mRNA transcript expression levels of Grp 78 and Hsp 70 were determined by real-time reverse transcriptase PCR. Exposure of A549 cells to
$\mathrm{TiO}_{2} \mathrm{NPs}$ in the dose range of $25-500 \mu \mathrm{g} / \mathrm{ml}$ for 6 and $24 \mathrm{~h}$ did not significantly change the expression levels of either Grp78 or Hsp70 mRNA (Fig. 6). However, a slight dose-dependent numerical increase in the Hsp70 transcript levels was noted after $24 \mathrm{~h}$, but not $6 \mathrm{~h}$, exposure to the $\mathrm{TiO}_{2} \mathrm{NPs}$, and especially for the anatase form, but as already noted this was not statistically significant.

The expression level of the Grp78 and Hsp70 proteins, relative to that of the housekeeping $\beta$-actin gene, in A549 cells after $\mathrm{TiO}_{2} \mathrm{NPs}$ treatment in tissue culture were investigated by Western blot analyses. Similar to that observed for the mRNA transcript levels, both the anatase and rutile crystalline forms of $\mathrm{TiO}_{2} \mathrm{NPs}$ did not significantly change the protein expression levels of Grp78 and Hsp70 after 6, 12 and $24 \mathrm{~h}$ of exposure, at least in the dose range examined in this study (Fig. 7).

\section{Discussion}

$\mathrm{TiO}_{2} \mathrm{NPs}$ are increasingly being used in various commercial products, but there is still an inadequate knowledge concerning their risk to human health and the environment,

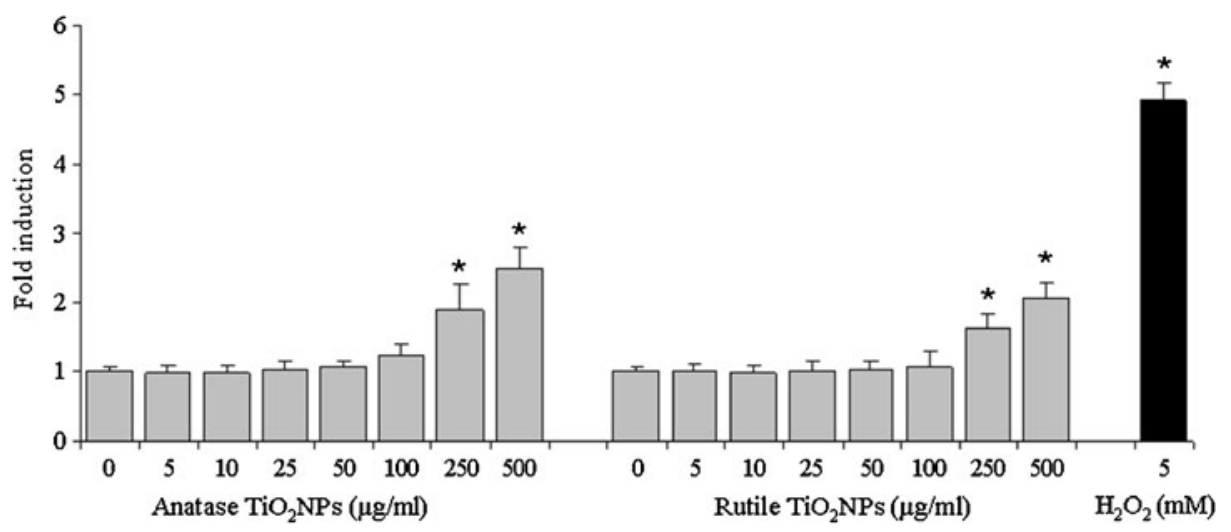

Fig. 3 Intracellular ROS generation in A549 cells after treatment with the $\mathbf{a}$ anatase and $\mathbf{b}$ rutile crystalline forms of $\mathrm{TiO}_{2} \mathrm{NPs}$. The cells were incubated with various concentrations of the anatase or rutile crystalline form of $\mathrm{TiO}_{2} \mathrm{NPs}$ for $24 \mathrm{~h}$ and then the intracellular ROS levels were determined by the DCF assay. $\mathrm{H}_{2} \mathrm{O}_{2}$ at $5 \mathrm{mM}$ was used as a positive control. Data are presented as the mean \pm SD of three independent experiments, and show the ROS levels relative to that of the no- $\mathrm{TiO}_{2} \mathrm{NPs}$ control. ${ }^{*} p<0.05$, using one-way ANOVA for the comparison between untreated and $\mathrm{TiO}_{2} \mathrm{NP}$-exposed cells 


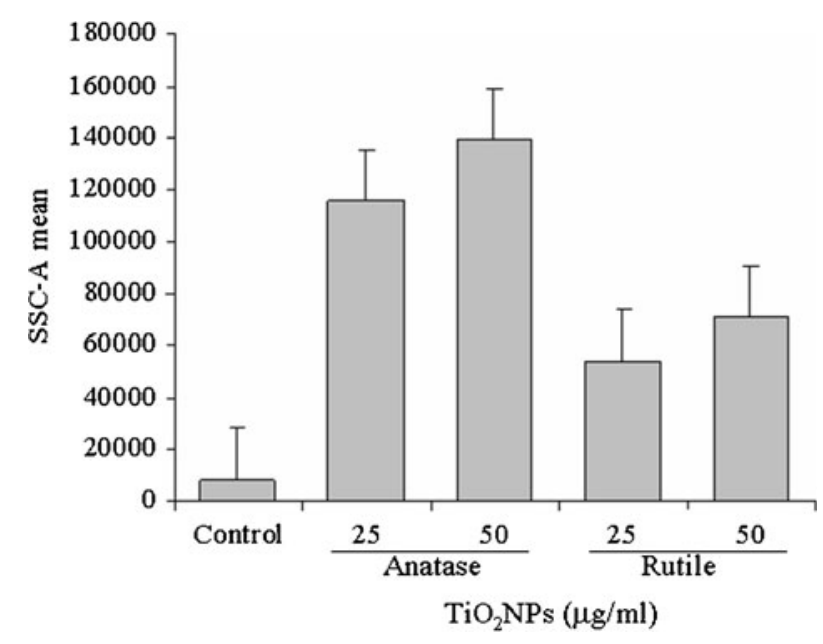

Fig. 4 Uptake of $\mathrm{TiO}_{2} \mathrm{NPs}$. A549 cells were treated with anatase and rutile $\mathrm{TiO}_{2} \mathrm{NPs}$ at 25 and $50 \mu \mathrm{g} / \mathrm{ml}$ for $24 \mathrm{~h}$ and were subjected to FACS analysis. $\mathrm{TiO}_{2} \mathrm{NP}$ uptake or cell surface adsorption is proportion to an increase in SSC-A of cell population

as well as on any suitable biomarker(s) for assessing the safety of $\mathrm{TiO}_{2} \mathrm{NPs}$ in, for example, the human respiratory system. In this study, we, therefore, investigated the in vitro cytotoxicity of both the anatase and rutile crystalline forms of $\mathrm{TiO}_{2} \mathrm{NPs}$ in $\mathrm{A} 549$ cells as an in vitro model of human

Fig. 5 TEM images of $\mathrm{TiO}_{2} \mathrm{NP}$ inside the cells. A549 cells were treated with anatase and rutile $\mathrm{TiO}_{2} \mathrm{NPs}$ at $100 \mu \mathrm{g} / \mathrm{ml}$ for $24 \mathrm{~h}$. a Untreated control; b-d anatase $\mathrm{TiO}_{2} \mathrm{NPs}$, where $\mathbf{d}$ is an increased magnification image of the circle area in $\mathbf{b} ; \mathbf{e}-\mathbf{g}$ rutile $\mathrm{TiO}_{2} \mathrm{NPs}$, where $\mathbf{g}$ is an increased magnification image of circle area in $\mathbf{e}$ and $\mathbf{f}$. The arrows indicate clumps of $\mathrm{TiO}_{2} \mathrm{NPs}$ in endosomes located in the cytoplasm. The arrowheads indicate nuclear membrane. $N$ nucleus bronchial epithelial cells and the possible biomarker(s) for evaluating the $\mathrm{TiO}_{2} \mathrm{NPs}$-induced cytotoxicity in respiratory system by focusing on HSPs family.

In toxicological studies, the drug or toxin-sensitive genes whose expression levels correlate with, or ideally are directly responsible for, the effect of the external stimuli (such as cytotoxicity here) can be useful as biomarkers for the effect. Among the biomarkers that have been studied, the expression levels of HSPs are widely used to monitor cellular hazards, because of their sensitivity to even minor assaults and their inducible nature against a wide range of chemicals [14]. Indeed, many toxicants alter HSP gene (transcript and protein) expression levels, in addition to various other stimuli including heat, pesticides, heavy metals, solvents, industrial and municipal effluents, some drugs, and mono- and polycyclic aromatic hydrocarbons [14, 21, 22]. Among the members of the Hsp70 family, the expression of Hsp70 and Grp78 are reported to be altered in response to various metal salts (including NPs) in several organs, including the lungs, both in the in vitro and in vivo models. For instance, the induction of Hsp70 protein expression was observed following silver NP treatment in Drosophila melanogaster, an often used in vivo model [23], in cadmium chloride treatment in LLC-PK1 renal epithelial cells in vitro [24], and in copper oxide NP and nickel exposure
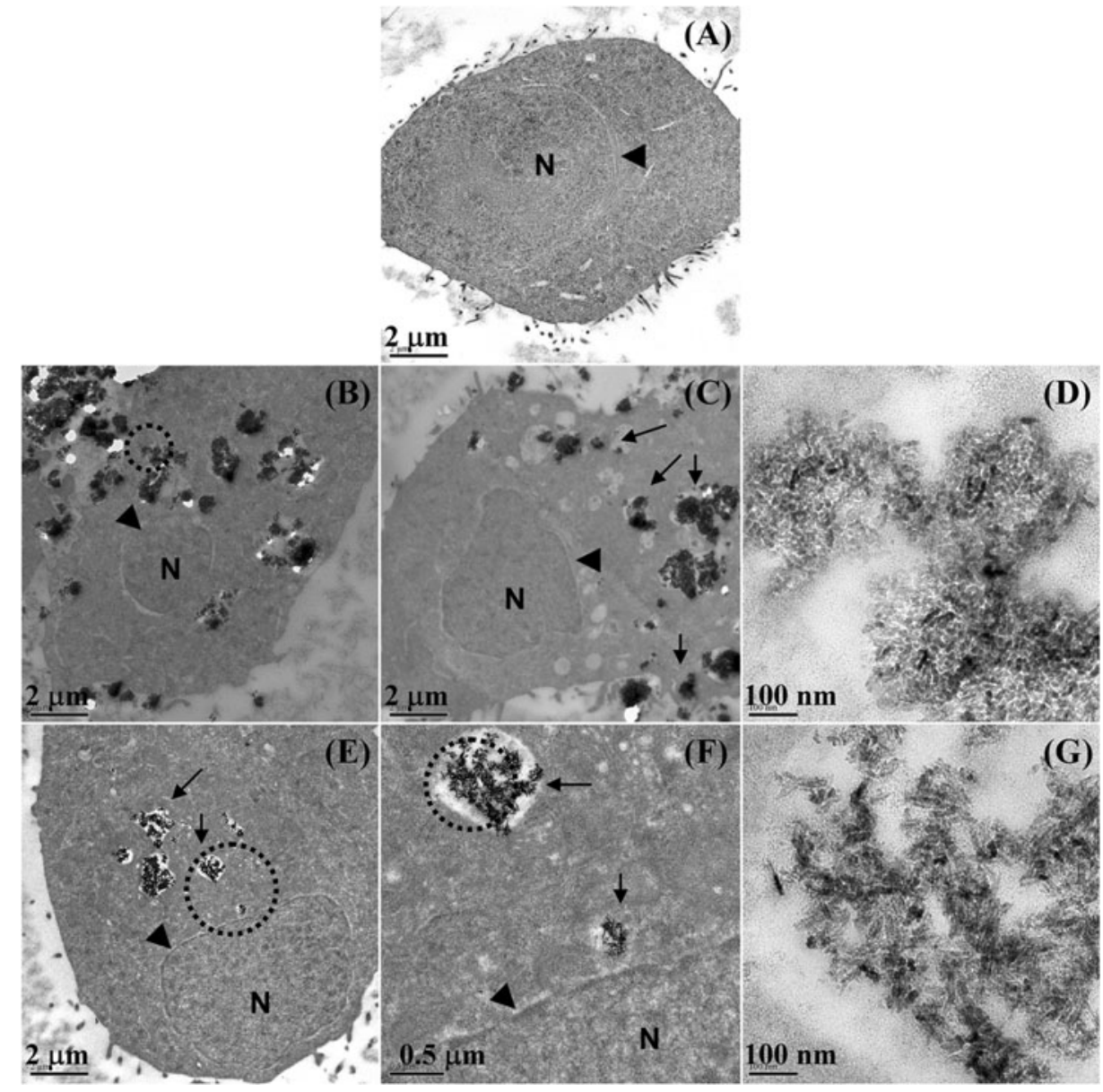
Fig. 6 Effects of the anatase and rutile crystalline forms of $\mathrm{TiO}_{2} \mathrm{NPs}$ on the $H s p 70$ and Grp78 transcript expression levels in A549 cells. A549 cells were treated with various concentrations of the anatase or rutile crystalline forms of $\mathrm{TiO}_{2} \mathrm{NPs}$ for 6 or $24 \mathrm{~h}$ and then the mRNA expression levels of Hsp 70 and Grp 78 were

determined by real time RTPCR. Data are shown as relative to that of the transcript housekeeping gene (GADPH), and are presented as the mean $\pm \mathrm{SD}$ of three independent experiments
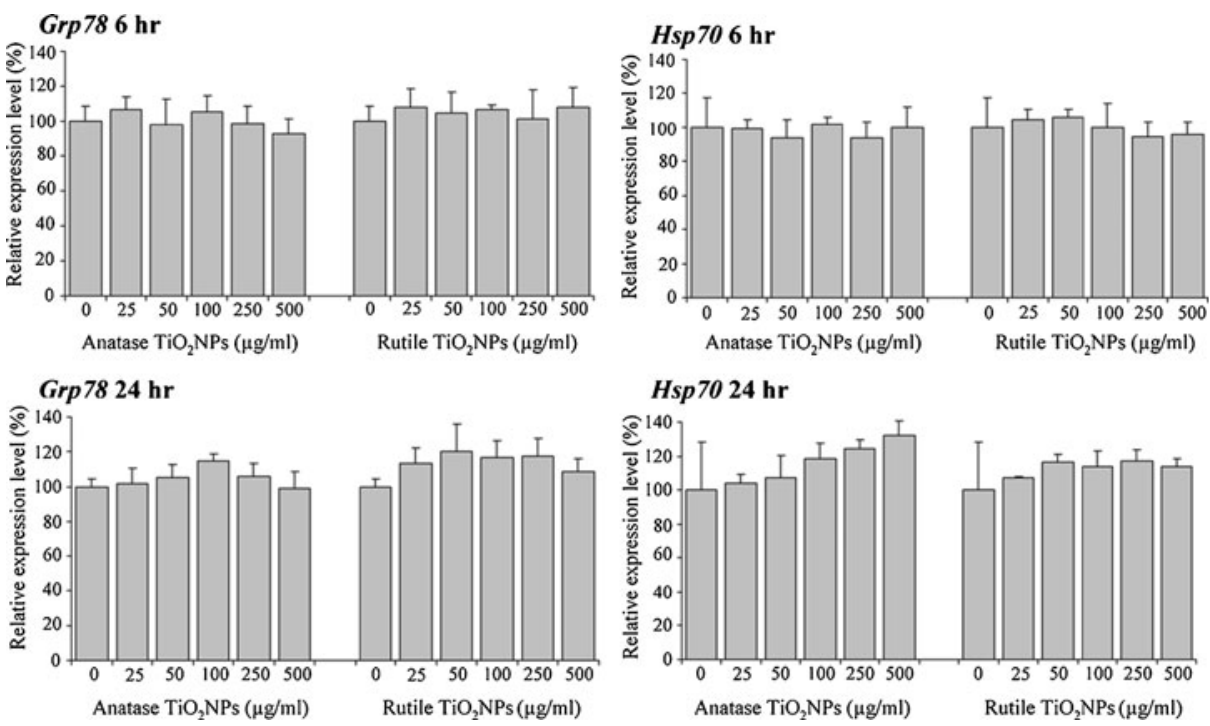

in A549 and Calu-3 human lung epithelial A549 cells [25, 26]. Likewise, an increased expression level of the Grp78 protein has been clearly observed after cadmium chloride exposure in several cell line types, including the LLC-PK1 renal epithelial cell line and rat lung epithelial cells [24, 27].

In the present study, we further investigated the possibility to apply the transcript and protein expression levels of Hsp70 and Grp78, two members of the HSPs family, as biomarkers


A549 cells as the exposure model [28]. For the $\mathrm{TiO}_{2} \mathrm{NPs}$ used in this study, TEM-EDX confirmed that the primary size of the $\mathrm{TiO}_{2} \mathrm{NPs}_{\mathrm{s}}$ were in the "nano" range (Fig. 1). However, the $\mathrm{TiO}_{2} \mathrm{NPs}$ tended to agglomerate in the hydrated forms, as determined by DLS (Table 2). $\mathrm{TiO}_{2} \mathrm{NPs}$ dispersed in $\mathrm{CM}$ showed the larger agglomerated size than $\mathrm{TiO}_{2} \mathrm{NPs}$ dispersed in DI water (Table 2). This might because of the interaction between $\mathrm{TiO}_{2} \mathrm{NPs}$ and serum components such as FBS and salts in the CM resulting in changing the agglomerated state $[29,30]$. Nevertheless, these agglomerates can be taken up by the cells and largely accumulated in the endosomes (Figs. 4 and 5), probably via endocytosis as reported previously shown the characteristic of lamellipodia engulfing $\mathrm{TiO}_{2} \mathrm{NP}$ aggregates [31]. Our results showed that the anatase and, to a lesser extent, the rutile crystalline forms of $\mathrm{TiO}_{2} \mathrm{NPs}$ caused cytotoxicity in a dose-dependent manner (Fig. 2), which correlates with the observed induction of intracellular ROS generation in the same cell line (Fig. 3). This is in agreement with a previous report that anatase $\mathrm{TiO}_{2} \mathrm{NPs}(<25 \mathrm{~nm})$ can cause cytotoxicity in A549 cells via oxidative stress and that pretreatment of the cells with dimethylthiourea, an $\mathrm{OH} \bullet$ scavenger, improved the cell viability [32].

Alteration of the expression levels of HSPs after exposure to toxicants associated with the induction of ROS generation has been reported previously in several studies [11, 20]. This oxidative stress is also one of the toxic insults that can disrupt normal protein folding in cells and lead to activation of the unfolded protein response [33]. In this investigation, even though we found the induction of intracellular ROS by
Fig. 7 Effects of the anatase and rutile crystalline forms of $\mathrm{TiO}_{2} \mathrm{NPs}$ on the Hsp70 and Grp78 protein expression levels in A549 cells. A549 cells were treated with various concentrations of the anatase or rutile crystalline forms of $\mathrm{TiO}_{2} \mathrm{NPs}$ for 6,12 or $24 \mathrm{~h}$ and then the expression levels of Hsp70 and Grp78 proteins were determined using Western blot analysis. Results represent blots from three independent experiments

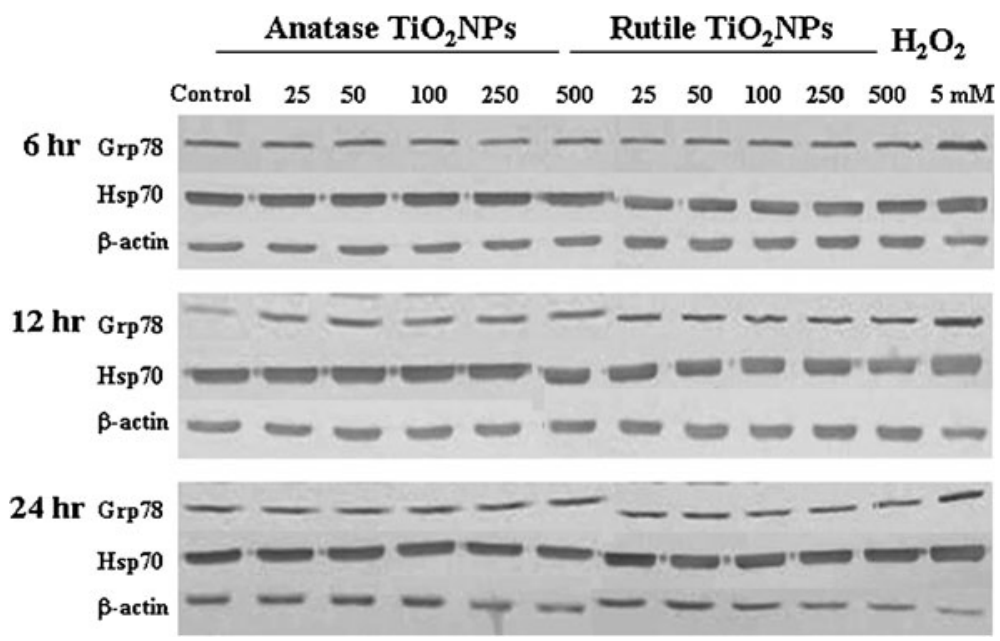


$\mathrm{TiO}_{2} \mathrm{NPs}$, we could not, however, observe any significant alteration in the Hsp70 and Grp78 expression levels at either the level of mRNA or protein (Figs. 6 and 7). The sensitivity in any biological response to external stimuli via these two HSPs is potentially chemical and cell type specific [24]. Heme oxygenase (Hsp32), one of the HSP family members, is very sensitive to $\mathrm{TiO}_{2} \mathrm{NP}$ exposure in the BEAS-2B human bronchial epithelial cell line, even at a dose that only causes $10 \%$ or less cytotoxicity [34]. However, in our study, even at $\mathrm{TiO}_{2} \mathrm{NP}$ doses that caused around $40 \%$ cytotoxicity and induced more than a 2-fold elevated ROS level ( $40 \%$ of the $\mathrm{H}_{2} \mathrm{O}_{2}$ control level), no significant change in the Hsp70 and Grp78 mRNA or protein expression levels were observed. This is despite the fact that it has been reported that Hsp70 and Hsp72 expression levels were increased in A549 cells after treatment with other metal NPs, such as copper oxide NPs, nickel and cadmium $[25,35$, 36]. Therefore, the cellular responses of Hsp70 and Grp78 to $\mathrm{TiO}_{2} \mathrm{NPs}$ in A459 cells might be metal specific, although we cannot exclude the possibility of a cell line-dependent affect, gene specific response, or due to experimental artifacts.

$\mathrm{Up}$ to date, the data on human exposure to $\mathrm{TiO}_{2} \mathrm{NPs}$ via inhalation are limited. Based on chronic inhalation studies in rats, NIOSH recommends airborne exposure limits of $2.4 \mathrm{mg} / \mathrm{m}^{3}$ for fine $\mathrm{TiO}_{2}$ and $0.3 \mathrm{mg} / \mathrm{m}^{3}$ for $\mathrm{TiO}_{2} \mathrm{NPs}$ for up to $10 \mathrm{~h} /$ day, during $40 \mathrm{~h} /$ week, to reduce risk of lung cancer over working lifetime [37]. It should be noted that the concentrations (up to $500 \mu \mathrm{g} / \mathrm{ml}$ ) used in our study were considerably high, in order to determine the mechanistic toxic effects. However, since there is less correlation between toxicity of nanoparticles in vitro and in vivo [38], these biological responses might not directly reflect in vivo results.

Taken together, our results suggest that $\mathrm{TiO}_{2} \mathrm{NPs}$ can cause cytotoxicity and ROS generation, but independently of altered Hsp70 and Grp78 expression levels in A549 cells. The actual involvement of these two gene products, however, remains unknown and awaits further evaluation, such as by gene silencing. Regardless, Hsp70 and Grp78 expression levels would appear to not be useful biomarkers for the biological response to $\mathrm{TiO}_{2} \mathrm{NPs}$ in the A549 cell line (the in vitro model of this study), and so potentially not in respiratory cells, although investigation in other models is still important.

Acknowledgements This work was financial supported by the Research, Development and Engineering Fund through the National Nanotechnology, NSTDA, Thailand. We thank Dr. Robert Butcher for comments and for the English language review.

\section{References}

1. Kaida T, Kobayashi K, Adachi M, Suzaki F (2004) Optical characteristics of titanium oxide interference film and the film laminated with oxides and their applications for cosmetics. J Cosmet Sci $55: 219-220$
2. Allen NS, Edge M, Sandoval G, Verran J, Stratton J, Maltby J (2005) Photocatalytic coatings for environmental applications. Photochem Photobiol 81:279-290

3. Higarashi NM, Jardim WE (2002) Remediation of pesticide contaminated soil using $\mathrm{TiO}_{2}$ mediated by solar light. Catal Today 76:201-207

4. Konstantinou IK, Albanis TA (2004) $\mathrm{TiO}_{2}$-assisted photocatalytic degradation of azo dyes in aqueous solution: kinetic and mechanistic investigation-a review. Appl Catal B Environ 49:1-14

5. Oberdöster G, Maynard A, Donaldson K, Castranova V, Fitzpatrick J, Ausman K, Carter J, Karn B, Kreyling W, Lai D, Olin S, Monteiro-Riviere N, Warheit D, Yang H (2005) Principles for characterizing the potential human health effects from exposure to nanomaterials: elements of a screening strategy. Particle Fibre Toxicol 2:2-8

6. Oberdöster G, Oberdöster E, Oberdöster J (2005) Nanotoxicology: an emerging discipline evolving from studies of ultrafine particles. Environ Health Perspect 113:823-839

7. Simon-Deckers A, Gouget B, Mayne-L'Hermite M, Herlin-Boime $\mathrm{N}$, Reynaud C, Carrière M (2008) In vitro investigation of oxide nanoparticle and carbon nanotube toxicity and intracellular accumulation in A549 human pneumocytes. Toxicology 253:137-146

8. Bhattacharya K, Davoren M, Boertz J, Schins RPF, Hoffmann E, Dopp E (2009) Titanium dioxide nanoparticles induce oxidative stress and DNA-adduct formation but not DNA-breakage in human lung cells. Particle Fibre Toxicol 6:1-11

9. Shi Y, Wang F, He J, Yadav S, Wang H (2010) Titanium dioxide nanoparticles cause apoptosis in BEAS-2B cells through the caspase 8/t-Bid-independent mitochondrial pathway. Toxicol Lett 196:21-27

10. Geiser M, Casaulta M, Kupferschmid B, Schulz H, SemmlerBehnke M, Kreyling W (2008) The role of macrophages in the clearance of inhaled ultrafine titanium dioxide particles. Am J Respir Cell Mol Biol 28:371-376

11. Golli-Bennour EE, Bacha H (2011) Hsp70 expression as biomarkers of oxidative stress: mycotoxin's exploration. Toxicology 287:1-7

12. Hartl FU (1996) Molecular chaperones in cellular protein folding. Nature 381:571-579

13. Schlesinger MJ (1990) Heat shock proteins. J Biol Chem 265:12111-12114

14. Gupta SC, Sharma A, Mishra M, Mishra RK, Chowdhuri DK (2010) Heat shock proteins in toxicology: how close and how far? Life Sci 86:377-384

15. Lanneau D, Wettstein G, Bonniaud P, Garrido C (2010) Heat shock proteins: cell protection through protein triage. Sci World $\mathrm{J}$ 10:1543-1552

16. Vos MJ, Hageman J, Carra S, Kampinga HH (2008) Structural and functional diversities between members of human HSPB, HSPH, HSPA, and DNAJ chaperone families. Biochemistry 47:70017011

17. Ni M, Zhang Y, Lee AS (2011) Beyond the endoplasmic reticulum: atypical GRP78 in cell viability, signaling and therapeutic targeting. Biochem J 434:181-188

18. Lee AS (2007) GRP78 induction in cancer: therapeutic and prognostic implications. Cancer Res 67:3476-3499

19. Suzuki H, Toyooka T, Ibuki Y (2007) Simple and easy method to evaluate uptake potential of nanoparticles in mammalian cells using a flow cytometric light scatter analysis. Environ Sci Technol 41:3018-3024

20. Yoshida Y, Shimakawa S, Itoh N, Niki E (2007) Action of DCFH and BODIPY as a probe for radical oxidation in hydrophilic and lipophilic domain. Free Radic Res 37:861-72

21. Maniratanachote R, Miami K, Katoh M, Nakajima M, Yokoi T (2005) Chaperone proteins involved in troglitazone-induced toxicity in human hepatoma cell lines. Toxicol Sci 83:293-302

22. Lu TH, Su CC, Chen YW, Yang CY, Wu CC, Hung DZ, Chen CH, Cheng PW, Liu SH, Huang CF (2011) Arsenic induces pancreatic 
$\beta$-cell apoptosis via the oxidative stress-regulated mitochondriadependent and endoplasmic reticulum stress-triggered signaling pathways. Toxicol Lett 201:15-26

23. Ahamed M, Posgai R, Gorey TJ, Nielsen M, Hussain SM, Rowe JJ (2010) Silver nanoparticles induced heat shock protein 70, oxidative stress and apoptosis in Drosophila melanogaster. Toxicol Appl Pharmacol 242:263-269

24. Liu F, Inageda K, Nishitai G, Matsuoka M (2006) Cadmium induces the expression of Grp78, an endoplasmic reticulum molecular chaperone, in LLC-PK1 renal epithelial cells. Environ Health Perspect 114:859-864

25. Forti F, Salovaara S, Cetin Y, Bulgheroni A, Tessadri R, Jennings P, Pfaller W, Prieto P (2011) In vitro evaluation of the toxicity induced by nickel. Toxicol In Vitro 25:454-461

26. Ahamed M, Siddiqui MA, Akhtar MJ, Ahmad I, Pant AB (2010) Genotoxic potential of copper oxide nanoparticles in human lung epithelial cells. Biochem Biophys Res Commun 396:578-583

27. Timblin CR, Janssen YMW, Goldberg JL, Mossman BT (1998) Grp78, Hsp72/72 and CJUN stress protein levels in lung epithelial cells exposed to asbestos, cadmium, or $\mathrm{H}_{2} \mathrm{O}_{2}$. Free Radical Biol Med 24:632-642

28. Rothen-Rutishauser B, Blank F, Mühlfeld C, Gehr P (2008) In vitro models of the human epithelial airway barrier to study the toxic potential of particulate matter. Expert Opin Drug Metab Toxicol 4:1075-1089

29. Thio BJR, Zhou D, Keller AA (2011) Influence of natural organic matter on the aggregation and deposition of titanium dioxide nanoparticles. J Hazard Mater 189:556-63

30. Allouni ZE, Cimpan MR, Hol PJ, Skodvin T, Gjerdet NP (2009) Agglomeration and sedimentation of $\mathrm{TiO}_{2}$ nanoparticles in cell culture medium. Colloids Surf B: Biointerf 68:83-87
31. Singh S, Shi T, Duffin AC, Berlo DV, Hohr D, Fubini B, Martra G, Fenoglio BPJA, Schins RPF (2007) Endocytosis, oxidative stress and IL-8 expression in human lung epithelial cells upon treatment with fine and ultrafine $\mathrm{TiO}_{2}$ : role of the specific surface area and of surface methylation of the particles. Toxicol Appl Pharmacol 222:141-151

32. Srivastava RK, Rahman Q, Kashyap MP, Lohani M, Pant AB (2011) Ameliorative effects of dimetylthiourea and $N$-acetylcysteine on nanoparticles induced cyto-genotoxicity in human lung cancer cells-A549. PLoS One 6:1-12

33. Malhotra JD, Miao H, Zhang K, Wolfson A, Pennathur S, Pipe SW, Kaufman RJ (2008) Antioxidants reduce endoplasmic reticulum stress and improve protein secretion. Proc Natl Acad Sci U S A $105: 18525-18530$

34. Park EJ, Yi J, Chung KH, Ryu DY, Choi J, Park K (2008) Oxidative stress and apoptosis induced by titanium dioxide nanoparticles in cultured BEAS-2B cells. Toxicol Lett 180:222-2229

35. Hfaiedh N, Allagui AS, El Feki A, Gaubin Y, Murat JC, Soleilhavoup JP, Croute F (2005) Effects of nickel poisoning on expression pattern of the $72 / 73$ and $94 \mathrm{kDa}$ stress proteins in rat organs and in the COS-7, HepG2, and A549 cell lines. J Biochem Mol Toxicol 19:12-18

36. Croute F, Beau B, Arrabit C, Gaubin Y, Delmas F, Murat JC, Soleilhavoup JP (2000) Environ Health Perspect 108:55-60

37. NIOSH. Current intelligence bulletin 63: Occupational exposure to titanium dioxide. Department of Health and Human Services. Centers for Disease Control and Prevention. National Institute for Occupational Safety and Health. DHHS (NIOSH) Publication No. 2011-160

38. Sayes CM, Reed KL, Warheit DB (2007) Assessing toxicity of fine and nanoparticles: Comparing in vitro measurement to in vivo pulmonary toxicity profiles. Toxicol Sci 97:163-180 